\title{
TRADE RELATIONS BETWEEN THE EUROPEAN UNION AND SOUTH AFRICA
}

\begin{abstract}
Sasha Vanja Franicevic*
Summary: The European Union's Common Agricultural Policy, often used as a shield of protection against foreign markets, has led to huge trade distortions in developing countries. Due to international pressure, the global trading giant has had to reform its internal policy measures to ensure a level playing field for all parties concerned. However, huge disparities still exist. South Africa, the African continent's largest economy, recently entered into a trade agreement with the European Union. The aim was to establish a free trade area over a 12-year period. The South African trade sector, largely unsupported by its government due to inadequate financial resources and policy infrastructure, now stands to compete with the European trading giant; a trading giant whose internal protectionist measures are the key to its internal market's survival and global superpower status.
\end{abstract}

\section{Introduction}

Over the last fifteen years, the South African economy has undergone enormous economic, political, and social change. ${ }^{1}$ The economy has been transformed by a series of policy reforms aimed at creating a more marketorientated economy. ${ }^{2}$ As part of the restructuring process, the South African government has focused its macroeconomic policy on stabilising the country's economic environment by attaching particular importance to foreign investment, acknowledging the important role such investment plays in reintegrating South African society into the international community. ${ }^{3}$

The South African government has therefore worked hard at developing its strategic alliances with global superpowers. It has continually sought ways in which to open up its markets to foreign investors, increasing its connections with the developing world. However, opening up its trade borders has often come at a price, a price the developing country has been willing to pay in order to gain access to one of the world's biggest and most prestigious markets: the European Union.

\footnotetext{
Recent graduate in Master of European Studies at the University of Zagreb, Croatia 1 OECD, 'OECD Review of Agricultural Policies - South Africa' (OECD, 2006) <http:// www.oecd.org/document/31/0,3343,en_2649_33797_36482847_1_1_1_1,00.html> accessed 2 May 2011.

2 OECD (n 1).

3 OECD (n 1).
} 
With the EU constantly seeking to develop untapped markets, South Africa is the perfect playground for the EU to invest in. A country with an abundance of natural resources and low production costs, South Africa has become the EU's $14^{\text {th }}$ largest trading partner. ${ }^{4}$

However, gaining reciprocal trade benefits from the global trading giant can be challenging. The EU follows a strict internal trade policy, ensuring above all the protection of its own internal market. Its protectionist stance towards its local markets is most visible in its agricultural sector. The EU's Common Agricultural Policy (CAP) has ensured the protection of EU producers, leaving little room for external influences that have the potential to disrupt its internal market. Due to a heavily subsidised market, European farmers have been able to enjoy limited export subsidies when entering foreign markets. ${ }^{5}$ By securing aid packages, and investing in EU production, CAP has ensured optimal value for its own producers, often to the detriment to those in the developing world.

With the EU using its superpower status to encourage less developed states such as South Africa to open up their markets, it has increased the market availability of often limited natural resources. In order for the EU to sustain its global trade supremacy, it needs to constantly explore ways in which to develop its internal market, and the key to this, it believes, is through untapped markets. The following paper seeks to explore the trade backgrounds of two diverse trading partners and how their internal trade policies are beginning to define their external trade relations.

\section{The EU as a key player in the global market}

The EU powerhouse of 27 Member States share a single market, a single external border, and a single trade policy. ${ }^{6}$ By working together as a solidified union, the EU has become the world's largest trading block. With a population of 495 million, the EU accounts for $20 \%$ of global trade. ${ }^{7}$

It is considered the world's biggest exporter of manufactured goods, designer goods, and high-value goods. ${ }^{8}$ The EU has become the single biggest market for imports from developing countries, exporting twice

\footnotetext{
${ }^{4}$ G Gambini, 'External Trade' (Eurostat: Statistics in Focus, 2010) $1<$ http://www.edsdestatis.de/de/downloads/sif/sf_10_042.pdf> accessed 12 May 2011.

5 P Goodison, 'EU's Common Agricultural Policy (CAP): Tools Protecting European Farmers' (South Centre, 2011) 3 <http://www.southcentre.org> accessed 13 May 2011.

6 Directorate-General for Trade, Europe's Trade Policy' (Europa, 2009) <http://trade. ec.europa.eu/doclib/docs/2009/may/tradoc_143154.pdf> accessed 10 January 2011.

7 European Commission, 'Living in the EU' (Europa, 2011) <http://europa.eu/about-eu/ facts-figures/living/index_en.htm> accessed 7 June 2011.

8 European Commission, 'Wise Choices?' (Europa Diary, 2009/2010) <http://www. ec.europa.eu/consumers/empowerment/cons_education_en.htm\#diary> accessed $10 \mathrm{Ja}-$ nuary 2011.
} 
the amount in return. ${ }^{9}$ It is also the biggest investor in underdeveloped countries, contributing nearly $50 \%$ towards global aid. ${ }^{10}$ By continually investing in new markets, the EU is regarded as being a forerunner in trade liberalisation and development. As an exporting economy, the EU relies upon open markets, benefiting substantially from market liberalisation in developing states.

\subsection{EU trade policy}

Between 2000 and 2007, the average value of extra-EU-27 exports was EUR 1.241 billion, whilst the value of imports averaged nearly EUR 1.434 billion. ${ }^{11}$ The EU is characterised by a permanent but generally limited trade deficit, reaching nearly USD 31.793 million. ${ }^{12}$ This limited trade deficit has enabled the EU to gain a huge amount of influence in the international trade sector. The EU's trade policy is based on maximising internal development. In order to sustain its internal market, it constantly seeks out new trading opportunities that could increase investment opportunities and growth for the European community. It therefore follows a multilateral liberalisation approach to its external trade policies, and a regional integration approach regarding its internal trade policy.

A firm believer in multilateral trade liberalisation, the EU uses trade as a tool for development in order to boost economic growth and increase job prosperity within the Union. ${ }^{13}$ The EU also holds that in order to increase European prosperity within the Union, it needs to expand its trade market, and that the key to this is developing untapped markets.

The core philosophy governing the EU internal market is the free movement of goods, services, capital and labour, and undistorted competition and non-discrimination. As the overall prosperity of the EU is dependent on market-driven economic success, it has worked hard at developing its expansion policies, as well as developing supportive structures and mechanisms on which Member States can rely. ${ }^{14}$

The EU prides itself on its single market. It has, and continues to develop, measures that guarantee compliancy standards are met in all areas, thereby ensuring the four freedoms are adhered to throughout

\footnotetext{
9 S Meunier, Trading Voices: The European Union in International Commercial Negotiation (Princeton UP 2005) 3.

10 Meunier (n 9).

11 Economic Commission for Africa, 'Trade Experience beyond Africa' (Assessing Regional Integration in Africa IV: Enhancing Intra-African Trade, May 2010) 469 <http://www.uneca.org/aria4/chap13.pdf> accessed 16 January 2011.

12 Economic Commission for Africa (n 11).

13 Directorate-General for Trade (n 6) 6.

14 Directorate-General for Trade (n 6) 6.
} 
the Union. Internally, it has removed internal border obstacles to trade, including the elimination of all exchange controls. ${ }^{15}$ This internal crossborder trading solidarity has ensured market success, giving the EU a vast amount of trading power within the international community.

\subsection{The EU's role in international markets: the WTO}

The fact that the EU is made up of the superpowers of Europe has enabled it to hold a dominant position within the international trading system and, more importantly, the WTO. From GATT through to the establishment of the WTO, the European Union has played a pivotal role in influencing international trade through numerous trade agreements.

As one of the founding members of the WTO, the EU has left significant footprints on the institutional design of the organisation. ${ }^{16}$ This has afforded it the ability to maintain a powerful stronghold on the development of the WTO and its trading developments. The EU has actively used its influence in the WTO to encourage the development of new markets, whilst breaking down barriers with existing trading partners.

Its stronghold within the international arena has allowed it to affect the outcome of trade disputes and settlements, influencing the way in which world trade is conducted. The fact that the EU has the ability to initiate and change international trade policies, as opposed to simply reacting to them, affords it a rather large amount of leverage within the global economy. ${ }^{17}$

\section{EU protectionism in agriculture}

'Free trade' is a term frequently used but practised very little. To the $\mathrm{EU}$, free trade is what drives its external trade policy on, prompting developing states to open their markets, encouraging them to ride on the wave of trading success. However, very few states have gained access to the dream world that the EU claims will come with an open-door trade policy, mainly because the EU does not actively practise what it is preaches.

The EU follows a twin approach to its trade policies. Outside its borders, it encourages an orderly global trading system, promoting trading alliances, adherence to WTO principles, and encouraging existing WTO members to invest in developing economies to increase their own market development. However, the EU has a very different policy within its internal borders. It maintains a protectionist stance towards its market

\footnotetext{
15 Directorate-General for Trade (n 6) 6.

$16 \mathrm{KE}$ Jorgensen, The European Union and International Organisation (Taylor \& Francis 2009) 190.

17 Meunier (n 9) 20.
} 
economy, like that of a rooster over its pen, fiercely protecting various trade sectors, arguably its agricultural sector the most.

The rapid increase in globalisation over the last few decades has obviously fuelled the existing need for protectionism by states. ${ }^{18}$ Never before has it been so essential for countries to shield themselves from external trade threats. The fight over world supremacy by claiming territorial domination has turned into an economic race in order to obtain the prize of being the biggest and brightest economic trading power. ${ }^{19}$ As a result of globalisation, economies and world markets have become so reliant on one another that it is essential that trading partners have a continental dimension. ${ }^{20}$ Countries now have a vested interest in developing new markets, encouraging those which lag behind to enhance their trading abilities, thereby increasing international dependency. The demands of the international system now require a certain level of openness in states' internal markets.

However, the EU is working fiercely to protect its internal market, albeit only as much as the international environment will allow. It is said to combine liberalism within its borders and a mercantilist approach outside. $^{21}$

Even though the EU might have the financial capabilities to support its agricultural sectors within the Union, its agricultural level of output is outmatched by that of markets such as Latin America. This is purely due to an abundance of agricultural resources and ideal climatic conditions, something which money cannot buy. In order to sustain its global market supremacy, the EU therefore needs to support its market in any way that it can so that it is able to compete at the international level, thereby ensuring that it is not excluded from the global agricultural market. In order to maintain its superpower status in the global sphere, it needs to portray itself as a self-sustaining unit, free from international market fluctuations that could topple its economic and political supremacy.

Its internal protectionist measures are therefore vital to its place in the world market. If it were to eliminate all protectionist measures, its internal market would be drowned by countries that are more suitably adapted to producing the amount of agricultural produce needed to support a society.

\footnotetext{
18 B Stokes, 'The Protectionist Myth' (1999) 117 Foreign Policy 88, 93.

19 Stokes (n 18).

20 European Parliament, 'The Lisbon Strategy: Objectives' (2009) <http://circa.europa.eu/ irc/opoce/fact_sheets/info/data/policies/lisbon/article_7207_en.htm> accessed 23 June 2011.

${ }^{21}$ M Wolf, 'Cooperation or Conflict? The European Union in a Liberal Global Economy' (1995) 71(2) International Affairs 325, 333.
} 


\subsection{Agricultural support}

The EU has been largely criticised for its protectionist measures towards its agricultural sector. The comparative advantage that the EU creates for its farmers in the Union far surpasses that of developing countries. The problem that mainly arises is not that the EU supports its agriculture and trade sector, it is that developing countries do not have the means or financial ability to do so, or at least not at the level at which the EU is able to. This therefore leaves developing countries at a complete disadvantage.

These developing countries, especially countries such as South Africa, do not have the financial capability to be able to compete with EU agricultural goods. This is not to say that their products are not of the same standard or are produced at a higher price: on the contrary. Southern Africa has one of the most sought-after agricultural climates in the world. Its diverse climatic regions enable a vast amount of produce to be harvested and developed. However, production and distribution to EU markets are often hindered by financial limitations and insufficient available resources.

The problem that develops therefore is that EU protectionist measures in its trade policies towards the South are disallowing the free flow of agricultural goods at a competitive price, or rather at a price which both parties are able to afford. For the South, the agricultural protectionist measures are too strong for it to become an equal trading partner with the EU. Often, developing countries that enter into trade relations with the EU are disillusioned with the effects on trade that EU trade quotas and tariff prices will have on their internal markets.

However, due to global pressure, the EU has been forced to lower its protectionist stance towards its external trade policy, having being criticised for imposing the most costly and market-distorting of all industrial policies within its sector. ${ }^{22}$ Trade protection in the EU has therefore had to undergo serious policy reforms, with agriculture being the most debated and contentious topic during the 1986 Uruguay Trade Negotiations and the Doha Development Round Negotiations in 2001. ${ }^{23}$ As a result of the trade negotiations, the EU was forced to seek reductions in 'all direct and indirect subsidies' affecting agricultural trade. ${ }^{24}$ However, although a step in the right direction, these necessitated reductions and policy reforms that might have gone too far for weaker or less developed states.

\footnotetext{
22 Pressure was largely felt from the United States, as it threatened to impose sanctions if the EU failed to comply with the necessary internal reform measures. R Paarlberg, 'Agricultural Policy Reform and the Uruguay Round: Synergistic Linkage in a Two-Level Game?' (1997) 51(3) International Organization 413, 416.

23 Paarlberg (n 22) 413.

24 Paarlberg (n 22) 413.
} 


\subsection{Agricultural protectionism in the internal market}

Extreme forms of trade protection by developed countries, especially in areas such as the EU, are still regarded as an anomaly by economists. This is mostly because the cost of protectionism, especially agricultural protectionism, often outweighs the benefits to society as a whole. ${ }^{25}$ Economists argue that the nature of trade and market supply is vastly distorted, as countries are denied the ability to trade the agricultural products that they have a natural comparative advantage in producing. ${ }^{26}$ Agricultural subsidies are therefore are at the expense of the consumer and taxpayer. ${ }^{27}$

There is little doubt that a majority of the population in industrialised countries would benefit from a reduction in agricultural support. Government subsidisation of agricultural production leaves the consumer benefiting from lower prices of agricultural goods, but at the same time consumers are left paying high levels of taxes in order to compensate for the market distortion. ${ }^{28}$ However, despite the high consumer price that comes with agricultural subsidisation, the EU remains firm on the need for agricultural support throughout the Union, highlighting the developmental advantages and structural reforms that come with government support.

The EU has therefore structured its Common Agricultural Policy (CAP) in such a way that it keeps trade flows between the EU and developing countries smaller than they otherwise would be if there were no EU government support measures in place. Due to market distortions and unrepresented value in trade, developing countries are required to integrate even further into global markets to ensure future economic growth and development within their own regions. ${ }^{29}$

The EU uses a plethora of policy instruments to protect its agricultural sector, ensuring continual production for its internal as well as external markets. ${ }^{30}$ EU CAP subsidies amount to nearly EUR 50 billion a year, plus an additional 10 billion a year in co-financing from Member States' national budgets. ${ }^{31}$ However CAP support is moving away from traditional market-management tools, such as price arrangements, pro-

\footnotetext{
${ }^{25}$ CG Thies and S Porche, 'The Political Economy of Agricultural Protection' (2007) 69 The Journal of Politics 116, 116.

26 Thies and Porche (n 25).

${ }^{27}$ Jong Hee Park and N Jensen, 'Electoral Competition and Agricultural Support in OECD Countries' (2007) 51(2) American Journal of Political Science, 314.

28 Park and Jensen (n 27) 315.

29 F Sinabell, 'Developing Countries and EU Agricultural and Food Policy' in A Oskam, G Meester and H Silvis (eds), EU Policy for Agriculture, Food and Rural Areas (Mansholt Publication 2010.

30 Goodison (n 5).

31 Goodison (n 5).
} 
duction quotas and export subsidies, towards a more direct producer support system.

Since its inception, CAP has undergone numerous reforms that have not only affected the EU's agricultural support system, but also that of global agricultural markets.

\subsection{CAP 2013 initiatives}

Since its establishment in 1962, the main objective of the EU's Common Agricultural Policy has been to ensure an adequate supply of food for all EU Member States. ${ }^{32}$ Achieving this objective was to be met by continual technological progress within the sector; optimum utilisation of the factors of production; and stabilisation of the markets, ensuring the continual availability of supplies to consumers. Above all, CAP was to ensure a fair standard of living to all those committed to the agricultural sector.

With these goals in mind, CAP sought to develop several instruments in order to attain its objectives. The most important objective was to maintain high producer prices through the establishment of price intervention or a minimum growth price system. ${ }^{33}$ Price intervention allowed national agencies to buy and store surplus products under the incentives of CAP. ${ }^{34}$ Through this system, EU farmers were guaranteed a minimum selling price for their agricultural products, no matter the disparities between the EU and international markets. ${ }^{35}$

CAP also established an entry price in order to protect prices within the Union. ${ }^{36}$ The entry-price system sought to establish a minimum price at which agricultural products could be imported into the Union. ${ }^{37}$ It was designed to prevent goods from coming into the market at a lower price, thereby undermining EU products. Agricultural exports from the Union also enjoy an export subsidy: the 'refund'. EU producers are paid a certain amount for their exports in order to close the gap between lower world prices and the higher prices within the Union. ${ }^{38}$ Amongst the products protected by the intervention mechanisms, sugar became a priority.

Initially developed as a price management system, CAP sought to maintain and favour internal EU prices against world market prices. This

32 European Parliament, 'Reform of the Common Agricultural Policy' (2010) $1<$ http://www. europarl.europa.eu/ftu/pdf/en//FTU_4.2.2.pdf> accessed 23 June 2011.

33 O Odek, 'Impact of EU-CAP Reforms in East Africa' (Friedrich Elbert Stiftung, 2003)

4 <http://www.fes.de/cotonou/downloads/fesdownloads/.../IMPACTOF.EU-.PDF> accessed 2 May 2011.

34 Odek (n 33) 4.

35 Odek (n 33) 4.

36 Odek (n 33) 4.

37 Odek (n 33) 4.

38 Odek (n 33) 4. 
system is therefore one of commodity preference, assigning priority to local products rather than imports. ${ }^{39}$

Through CAP 2013, the Union has carried out a radical shift from production support to producer support, thereby making CAP and EU farmers more market-orientated. ${ }^{40}$

At the heart of the producer-support system is the single payment scheme of direct aid payments to EU farmers, with price support mechanisms having been gradually transformed into decoupled direct payments. The single payment schemes are supported by numerous rural development measures designed to enhance the competitiveness of EU food and agricultural production and promote the economic diversification of rural areas. Over and above the producer-support system, the EU also implements, to varying degrees, traditional trade policy tools, such as MFN import tariffs, tariff rate quotas (TRQs), seasonal TRQs, minimum import prices, and import and export licenses. ${ }^{41}$

The EU applies its internal policy rules of direct aid payments to farmers; investment support tools; new policy instruments; national support to agriculture; transitional measures and emergency programmes; and lastly, traditional agricultural trade policy tools in order to maintain its competitive advantage on the market. ${ }^{42}$ The above measures provide the EU with a competitive edge, allowing it to maintain its key role and trading position on the international market. These direct aid and funding tools enable it to protect its internal market while establishing future developments that put it ahead of the game.

The main problem, however, is how these protectionist tools of its internal market affect relations with its external trading partners. The overall effect of CAP on developing countries varies. The overall cost of CAP to the global economy through resource misallocations and missed trade opportunities is USD 75 billion. ${ }^{43}$ The next section will examine trade relations between the EU and South Africa, and how the EU's protectionist measures are damaging the trade opportunities and development of the southern hemisphere.

\footnotetext{
39 Odek (n 33) 5.

40 European Parliament: Committee on Agriculture and Rural Development, 'Draft Report on the Future of the Common Agricultural Policy after 2013' (2010) $6<\mathrm{http}$ ://www.europarl.europa.eu/meetdocs/2009_2014/.../810067en.pdf> accessed 12 May 2011.

41 European Parliament (n 40) 3.

42 European Parliament (n 40) 4.

43 M Leen, 'Integrating the International Development Goals into Europe's Trade Policy and Practice: The Challenges of CAP Reform' (Trócaire, 2002) <http://www.trocaire.org/ resources/tdr-article/integrating-international-development-goals-europes-trade-policyand-practice> accessed 6 May 2011.
} 


\section{South Africa-EU trade relations}

In 2009, South Africa was ranked as the European Union's $14^{\text {th }}$ largest global trading partner, and the $2^{\text {nd }}$ largest from Africa. ${ }^{44}$ Currently, the European Union is South Africa's largest single export market. South Africa, a country rich in natural resources, with a population of nearly 50 million people, is regarded as the most financially and politically stable country in Africa. While comparatively a developed country, there are still large portions of the population that live in complete poverty. With the EU providing nearly $70 \%$ of all external assistance funds, it has become the most important developmental aid supplier and trading partner to South Africa. ${ }^{45}$ In turn, this makes the South African economy largely dependent on the EU for its own internal market success.

\subsection{South African trade}

Over the last 17 years, South Africa has transformed itself from an import-substituting industrialisation regime to an export-orientated one. The result is a more open and market-orientated economy. Prior to policy reform, tariff and non-tariff barriers dominated the country's trade regime, thereby limiting any form of foreign competition. By gaining entry into the WTO, South Africa welcomed a completely new trading environment. Entry into the WTO not only tested the quality of its products and its ability to service a market much bigger than its own, but also helped in establishing a certain level of competiveness that was required in order to succeed in such a demanding market.

Since 1994, and political transformation and entry into the WTO, the South African agricultural and trading sector has undergone many changes, increasingly integrating itself into world markets. After years of social and political exclusion, South Africa was determined to reintegrate into international markets. Economic integration and political cohesion therefore become a top priority for the South African government.

South Africa's diverse range of agricultural and trading goods is a direct result of its varied climatic regions. From extensive deserts to humid coastal regions, South Africa prides itself on the abundance of its varied natural resources. South Africa currently has a dual-based agricultural economy, where a developed commercial sector co-exists with a large number of subsistence (communal) farms. ${ }^{46}$

South Africa's agricultural activities range from intensive crop production and mixed farming, to cattle ranching in the open wide plains,

\footnotetext{
44 Gambini (n 4).

45 European Commission, 'Bilateral Relations: South Africa' (EUROPA, 2009) <http:// ec.europa.eu/trade/creating-opportunities/bilateral-relations/countries/south-africa/> accessed 13 May 2011.

46 OECD (n 1).
} 
and sheep farming in the arid regions. Due to these varied resources, it is one of the world's leading exporters of wine, sugar, fresh fruit, nuts, beverages, preserved food, tobacco, cereals, wool, meat, milling products, malt and starch. South Africa is also amongst the world's top five exporters of avocados, grapefruit, tangerines, plums, pears, table grapes and ostrich products. However, the majority of South African exports to the EU are fruit, coal, coca cola, and non-metallic manufactured mineral products from the region.

In 2006, a study compiled by the Organisation for Economic Cooperation and Development (OECD) stated that nearly a third of South African produce was exported, making the South African agricultural and produce sector largely dependent on global markets. ${ }^{47}$ Increased agricultural and produce exports, especially high-value agricultural commodities (fruit, vegetables, milk, meat, eggs, fish) and value-added products (raw materials that are then modified or enhanced) are considered pivotal in providing the growth impetus needed for the South African agricultural sector. ${ }^{48}$ In order for this to happen, the South African Department of Agriculture, Forestry and Fisheries (DAFF) aims to increase competitiveness, raise net exports and increase South Africa's trade as a share of world trade. It hopes this will improve the overall trade composition and comparative advantage that South Africa has over its local competitors. The most important thing for South Africa is to raise its trade competiveness to the level of that of the EU. This, DAFF believes, will solidify its trading ability within the global market.

\subsection{Government support}

Due to the influx of trade and investment into the country over the last few years, the South African government has sought to establish measures that protect its local producers. As the local agricultural markets are largely unsubsidised by the government, state officials have sought to create ways to protect local producers from external influences.

In 1996, the government passed the Marketing of Agricultural Products Act. ${ }^{49}$ The Act, aimed at protecting South African farming from unfair international competition, sought to close agricultural marketing boards, phase out certain import and export controls, eliminate subsidies, and introduce import tariffs. ${ }^{50}$ The South African government cla-

\footnotetext{
${ }^{47}$ OECD (n 1).

48 Department of Agriculture, Forestry and Fisheries, Economic Research Division, 'Competitiveness of Selected South African Agricultural Products in the European Union Market' (Department of Agriculture, Forestry and Fisheries Republic of South Africa, 2011) 2 <http://www.daff.gov.za/docs/Economic_analysis/2011_ER.pdf> accessed 3 May 2011.

49 OECD (n 1).

50 OECD (n 1).
} 
ims that deregulation of the industry has allowed for a leaner, stronger agricultural industry, enabling local producers to align themselves with international competitors.

The current level of PSE (Producer Support Estimate) is 5\%, relatively low in comparison to markets of a similar nature. ${ }^{51}$ Market price support remains the largest component of producer support. However, the level of government support in the agricultural sector is remarkably uneven across commodities, with sugar being the most supported commodity.

There has also been a significant decrease in budgetary payments in the sector, with the remaining budget support targeted towards research, training, inspection and infrastructure development. ${ }^{52}$ A lack, or rather low level, of government support in the sector is largely due to inadequate supporting infrastructure. Public expenditure in the current structure and policy framework can be said to be a direct result of the historical trends and politics of the country rather than the needs of the sector. Despite this, the South African government has worked hard to re-establish its agriculture and trade sector, although it is constantly hindered by a lack of budgetary allowances for the industries. The total cost of support to the agricultural sector has fallen from $1 \%$ of GDP to a mere $0.59 \% .{ }^{53}$ This is rather low, given that the average levels of support to countries such as those in the EU are $0.97 \% .54$

In order to increase global competiveness, South Africa recently adopted The South African Agricultural Production Strategy 2011-2015.55 The strategy is aimed at improving agricultural support mechanisms to enable increased integration with world markets, in particular its main trading partner, the EU. However, despite economic gains from trade liberalisation, major economic and social challenges remain. In the light of the EU's recent restructuring of its own agriculture and trade sector, South Africa has little chance of meeting the new challenges that these developments impose on its trade relations. South African farmers are already facing substantial financial pressure. Any more challenges in the market may leave them out in the cold.

South Africa is not the only developing market vying for EU attention. Steady competition from Australia, Argentina, Chile and Brazil keeps

\footnotetext{
51 OECD (n 1).

52 OECD (n 1).

53 Department of Agriculture, Forestry and Fisheries of the Republic of South Africa, 'South African Agricultural Production Strategy 2011-2015' (Department of Agriculture, Forestry and Fisheries of the Republic of South Africa, 2011) $10<\mathrm{http}: / /$ www.nda.agric.za/doaDev/ doc/IGDP/AGRIC_PRODUCTION_STRATEGY_FRAMWK.pdf> accessed 5 May 2011.

54 DAFF (n 53).

55 DAFF (n 53).
} 
the South African market on its toes and its attention constantly on developments within the EU. The necessity of alliance with the EU not only enhances market possibilities for South Africa, but also assists in developing global market opportunities.

\subsection{Benefits of an open market for South Africa}

Through international trade agreements, the South African economy has been transformed into a society that is filled with economic potential, and which is a playground for foreign investment. Its success is mainly based on the development of its internal market, allowing external players to change the level of the game. ${ }^{56}$ South Africa's counter-seasonality to Europe is a major competitive advantage. South Africa is the closest major southern hemisphere producer of agricultural and floricultural products to Europe, and has significantly shorter shipping times than those of its southern hemisphere trade rivals.

Whilst an integral member of the African, Caribbean and Pacific (ACP) group of countries, South Africa was not privy to the preferential trade agreements afforded to other ACP members under the Cotonou agreement of 2000, as it was regarded as a relatively developed nation, and was therefore found not to be eligible for many of the privileges afforded to other ACP states under the agreement. Although a signatory, it benefits from limited membership.

As South Africa is the continent's biggest economy, and is not considered as a least developed country, it fails to benefit from EU regulations that apply to other African states.

South Africa's trade relations and developmental policies towards the EU are therefore governed by a separate union, the Trade, Development and Co-operation Agreement (TDCA). The TDCA was ratified on 1 October 1999 in Pretoria, South Africa. However, it only fully entered into force in May 2004. ${ }^{57}$ The agreement aims to establish a free trade area over a 12year period between the two trading partners, covering $90 \%$ of bilateral trade. The agreement deals mostly with the free movement of goods and services, but also provisions that include investment strategies.

Since the inception of the TDCA, South Africa has seen a rise in its EU exports from EUR 15.8 billion in 2004 to nearly EUR 22.2 billion in 2008. Trade volume has risen almost a third from EUR 31.8 billion in

\footnotetext{
56 OECD, 'Domestic Reforms Help South Africa Benefit From Freer Agriculture Trade' (OECD, 2006) <http: / /www.oecd.org/document/24/0,2340, en_2649_201185_36482904_1_1_1_1,00.html> accessed 12 May 2011.

57 Trade, Development and Co-operation Agreement (TDCA) [1999] OJ L $311<$ http://europa.eu/legislation_summaries/development/south_africa/r12201_en.htm> accessed 11 May 2011.
} 
2004. ${ }^{58}$ The agreement outlines several objectives: strengthening dialogue between the EU and South Africa; supporting South Africa in its economic and social transition process; promoting regional co-operation and economic integration in southern Africa; and expanding and liberalising trade in goods, services, and capital. ${ }^{59}$ The agreement is considered to have played an important role in integrating South Africa (a once mainly export-based country) into the global economy.

\subsection{Trade, Development and Co-operation Agreement (TDCA)}

The TDCA, in line with WTO trade rules, commits both the EU and South Africa to reducing tariffs based on the applied rates at the time of entering into the agreement. Under the agreement, trade goods are divided into agricultural and industrial products. ${ }^{60}$ The EU's interests are said to lie in development within the agricultural sector and the opening of its markets, whilst the South African government is more focused on the tariff eliminations that will be seen in the industrialised sector. The agreement is configured in such a way that reform of agricultural markets will take priority in the first half of the 12-year implementation period, with the elimination of tariffs in the industrial sector to be accessed in greater detail in the latter half of the timeframe. The observed asymmetry in the liberalisation of the sectors is to allow for different respective levels of development to take place in the interim. ${ }^{61}$

Under the agreement, the EU is to eliminate $95 \%$ of its tariffs on currently traded goods, whilst South Africa is to reduce its tariffs by $86 \% .{ }^{62}$ However, the changes in EU tariffs affect only $25 \%$ of its currently traded goods with South Africa, with the average EU tariff on these goods amounting to $2.7 \% .{ }^{63}$ The greater burden therefore seems to fall on South Africa, as tariff changes will affect $40 \%$ its currently traded goods with an average tariff of $10 \% .{ }^{64}$

\footnotetext{
58 European Commission, 'Bilateral Relations: South Africa' (EUROPA, 2009) <http:// ec.europa.eu/trade/creating-opportunities/bilateral-relations/countries/south-africa/> accessed 13 May 2011.

59 TDCA (n 57).

60 M Kalaba, R Sandrey and D Ernst van Seventer, 'Analysis of Trade between South Africa and the EU and a Preliminary Attempt to Examine the Impact of the EU/SA FTA on Trade' (Trade and Industrial Policy Strategies, 2005) 6 <http://www.tips.org.za/.../SA_EU_FTA_ Mid-term_Review_Final_Report_0.pdf> accessed 2 May 2011.

61 Kalaba, Sandrey and Ernst van Seventer (n 60).

62 C Grant, 'Southern Africa and the European Union: The TDCA and SADC EPA' (Trade Law Centre for Southern Africa, 2006) $3<$ https://www.givengain.com/unique/tralac/ pdf/20060518_TDCA_SADC_EPA_Grant.pdf> accessed 4 May 2011.

63 Grant (n 62) 3.

${ }^{64}$ Grant (n 62) 3.
} 
South Africa was further requested to liberalise its agricultural sector by eliminating $81 \%$ of tariffs on EU agricultural exports to South Africa within the set timeframe, with an additional agreement to eliminate at least $46 \%$ of tariffs within the first five years. ${ }^{65}$ In comparison, it was agreed to eliminate a mere $62 \%$ of tariffs on South African agricultural exports to the EU. ${ }^{66}$

However, South Africa has been careful to protect particular local products that are considered regionally sensitive. Not excluded from tariff reduction, but rather under review, these products include meat and preserved meat products, sugar and high sugar-content products such as chewing gum and cereals. Arguably, the greater burden on tariff reductions has therefore fallen on South Africa. Nevertheless, in 2004 the South African government claimed that trade between the European Union and South Africa had grown a staggering 50\% since the inception of the agreement, thereby restating their positive stance towards the agreement. However, South Africa seems to be the only southern African state that is fully content with the outcome of the TDCA. ${ }^{67}$

Due to trade diversion, the trade agreement between the EU and South Africa has resulted in a decrease in tariff revenue for neighbouring southern African states. Not only did the TDCA result in the elimination of previous trade agreements between the southern states, trade was swiftly diverted to the new trading partners. It was estimated that Botswana lost nearly $10 \%$ of its total national income because of the TDCA partnership. Due to the rules of origin within the provisions of the TDCA agreement, neighbouring states of South Africa are excluded from preferential access to EU markets. ${ }^{68}$

However, due to the recent economic climate, there has been a dramatic fall in South African trade with the EU. Between 2000 and 2008, EU-South Africa trade saw an incredible 61\% increase from EUR 26.5 billion in 2000 to 42.6 billion in $2008 .{ }^{69}$ During this period, exports grew by $71 \%$ and imports over $52 \% .{ }^{70}$ In the space of one year, the economic crisis changed things dramatically. Between 2008 and 2009, EU exports to South Africa fell by $20 \%$, with imports decreasing by a staggering $33 \% .{ }^{71}$ This significant fall in the market called for the EU to rethink and re-establish its trade mechanisms. It sought to restructure itself in such a way that it would protect its internal market from the grave collapse of the global market.

65 Grant (n 62) 3.

66 Grant (n 62) 3.

67 Grant (n 62) 3.

68 Grant (n 62) 4.

69 Gambini (n 4).

70 Gambini (n 4).

71 Gambini (n 4). 


\section{Disparities in the market: the example of the sugar sector}

The relationship between the European Union and South Africa is a classic example of a north-south relationship. South African exports are primarily natural resources and minerals, whilst its imports are mainly manufactured products from the EU. Due to the increase in dependency on European markets, South Africa has become market sensitive to the high levels of volatility in EU markets. As South Africa is the weaker player, it therefore absorbs more knocks in the financial market than the EU. Disruptions in its own internal markets are often caused by changes in the EU demand-and-supply chain of events.

However, the consequence of EU-South African trade agreements has often resulted in large disparities in the South African market. The sugar industry in South Africa has taken an incredible knock in trying to adjust to the EU standards required by the terms of the trade partnership between the two countries.

\subsection{Global sugar industry}

Sugar is among the most traded commodities, with exports accounting for nearly one quarter of global agricultural production. It is also one of the most distorted and contentious topics in the global trade arena.

Currently, the majority of sugar trade occurs through preferential trade agreements between two or more countries. Whilst these agreements establish new trading opportunities, they often lead to the elimination of other more economically viable trading producers from the sector.

The EU sugar sector is governed by the Common Market Organisation (CMO). Created in 1968, it was established with the aim of creating an internally protected market, free from external market influences. ${ }^{72}$ With EU producers guaranteed a stable income, the CMO sought the establishment of a self-sustaining sugar empire within the Union. ${ }^{73}$ In order to become a self-sustaining trading giant, the EU imposed significant measures to ensure its trading superiority on international markets. By encouraging the principal of community preference, domestically produced goods became favoured over imports.

From the moment the CMO was established, the EU sugar community became fiercely protected from any external competition. ${ }^{74}$ Import levies were applied to all sugar-related products entering the Union, and

\footnotetext{
72 European Commission, 'Reforming the European Union's Sugar Policy' (EUROPA, 2003) 8 <http://ec.europa.eu/agriculture/publi/reports/sugar/fullrep_en.pdf> accessed 13 June 2011.

73 European Commission (n 72).

74 European Commission (n 72).
} 
community production was largely influenced by community demand, with surplus stock dumped on the international market. ${ }^{75}$ For a long time, the EU sugar sector escaped internal reforms, and sugar reforms within the EU, or rather the lack thereof, went largely unnoticed.

For decades, the EU controlled the world sugar sector, claiming top world export status in the refined sugar market. ${ }^{76}$ According to Oxfam, with a production cost nearly double internationally competitive rates, it cost the EU nearly USD 600 to produce one ton of sugar, as opposed to USD 280 for competitive countries such as South Africa. ${ }^{77}$

Due to such high production costs, the only way that EU sugar producers could benefit from sugar exports was through government support measures. EU sugar producers therefore became the most protected sugar competitors on the international market. In order to maintain its stronghold over international markets, the EU was therefore required to implement stringent and complex import controls, price support and export subsidies.

Dependent on the world market for the vast majority of its sugar exports, and with no quota allowance, the South African sugar industry lost EUR 39-75 million annually because of EU protectionism during this period. $^{78}$

Through its government support measures, the EU was able to depress world prices, thereby discriminating against producers that were more efficient within the sector. By controlling the market, the EU was able to close the gap between its own high sugar prices and the considerably lower world ones. As a result, consumers were left paying incredibly high prices for sugar, and developing countries left struggling to maintain their internal markets due to the misrepresentation in the market.

EU government subsidies resulted in the over-production of sugar in the internal sector, allowing the EU to dump excess stock on the world market, pushing other sugar exporters out of it. ${ }^{79}$ Dumped sugar was then sold at world market prices, with Brazil the only country able to produce sugar at the disputed prices. ${ }^{80}$ This left developing countries struggling to survive in the face of protectionism and highly subsidised exports.

\footnotetext{
75 European Commission (n 72).

76 Oxfam, 'How the EU's Sugar Sector is Devastating Livelihoods in the Developing World' (Oxfam, 2002) 1 <http://www.oxfam.org.uk/resources/policy/trade/downloads/bp27_sugar.pdf> accessed 4 May 2011.

77 Oxfam (n 76) 4.

78 Oxfam (n 76) 4.

79 R Gibb, 'Developing Countries and Market Access: The Bitter-Sweet Taste of the European Union's Sugar Policy in Southern Africa' (2004) 42(4) The Journal of Modern African Studies 563, 581 .

80 Oxfam (n 76).
} 
At the start of 2000, the EU was embroiled in a trade battle in the sugar industry. It was lambasted by the World Trade Organisation and developing countries for not lowering its protectionist stance towards its sugar industry. ${ }^{81}$ The EU was accused of distorting the global sugar market due to the high levels of government support to the industry. EU government support to the industry was said to result in huge trade distortions, with domestic consumers forced to pay high prices for sugar, whilst developing countries were left facing depressed world prices and reduced trade opportunities.

In 2002, the EU was summoned before the WTO, and following international pressure was forced to liberalise its immensely distorted sugar regime. ${ }^{82}$ Countries argued that the highly protected EU sector was leading to large disparities on world markets, with damaging effects on future production. The reforms resulted in the elimination of intervention strategies and the introduction of a reference price in the sector. The EU agreed to a $36 \%$ reduction in product price to be phased in over four years. ${ }^{83}$

Reductions in subsidies have resulted in less over-production and therefore higher world prices due to a more limited supply in the sugar sector. However, a higher price has allowed lower-cost producers to reduce their own protectionist measures within the market.

Although these reforms did not completely readjust the markets towards a more liberal trading regime, they lowered the protectionist stance enough to allow the development of other markets to occur. After reducing its subsidies, the EU became the world's largest sugar importer.

\subsection{CAP's response to the sugar sector}

By the end of 2009, the sugar sector reforms agreed upon by the EU in 2005 had been fully implemented. ${ }^{84}$ The reform process resulted in the end of sugar production in five EU Member States, with further reductions of nationally allocated quotas in six Member States. ${ }^{85}$ Reductions were therefore consistent with the basic objectives of CAP reforms.

However, while production quotas were reduced, it did not automatically result in a decrease in the volume of sugar harvested. In June 2009, German sugar production was reported to have been $28.6 \%$ above the post-reform quota, even exceeding the pre-reform quota level. ${ }^{86}$ However,

81 Agritrade, 'Sugar: Trade Issues for the ACP' (Agritrade, 2010) < http:/ / agritrade.cta.int/ en/Commodities/Sugar-sector/Executive-brief> accessed 10 May 2011.

82 Agritrade (n 81).

83 Agritrade (n 81).

84 Agritrade (n 81).

85 Agritrade (n 81).

86 Agritrade (n 81). 
the EU insisted that overflows in the market were redistributed towards the facilitation of other sectors, such as the biofuels industry. ${ }^{87}$ The EU continues to reassure global market competitors that its crop production will shrink with time as its harvesting methods are slowly eliminated and the efforts and resources used targeted towards other sustainable means of production.

Therefore, in order to facilitate the global reform process, the EU has sought to re-establish its market management tools within the sector. Apart from the production quota system, the three basic tools that currently manage the EU sugar sector are export subsidies, the inward processing regime, and the management of tariff-rate quota-regulated imports. ${ }^{88}$ However, the EU plans to eliminate all export funds by $2013 .{ }^{89}$ The EU believes that effective management of the sector will ensure the long-term objective of closing the gap between high EU sugar prices and lower world ones.

\subsection{The South African sugar sector}

The South African sugar industry is ranked eighth in the world,,$^{90}$ with $50 \%$ of its production exported to global markets. Sugar plays a large role in the South African economy, accounting for a large portion of the employment sector. Due to this fact, the South African government is determined to establish trade agreements that will allow its local market to flourish in the globally distorted sugar sector.

Already facing the hard task of competing with the EU's protectionist measures, South Africa faces another obstacle in its flourishing market: water. With water demands predicted to outstrip available supply by $2030,{ }^{91}$ the South African government has assigned the utmost importance to maximising sugar production whilst it still has the means. The government has therefore sought to conclude an EPA (Economic Partnership Agreement) with the EU allowing it to export a certain quota of sugar to the EU market duty-free. This EPA, however, is a temporary measure until such time that the South African market is able to secure the full duty and quota-free access benefits that have been secured for other Southern African Development Community (SADC) members. Improved access to the EU sugar market will increase South African sugar sector revenues, reversing the decline that is currently being experienced in the local market.

\footnotetext{
87 Agritrade (n 81).

88 Agritrade (n 81).

89 Agritrade (n 81)

90 Illovo Sugar, 'International Sugar Statistics' (Illovo Sugar, 2011) <http://www.illovosugar.co.za/World_of_sugar/Sugar_Statistics/International.aspx> accessed 15 June 2011.

91 Brand South Africa, 'South African Agriculture' (SouthAfrica.info, 2008) <http://www. southafrica.info/business/economy/sectors/agricultural-sector.htm> accessed 14 June 2011.
} 
The trade agreement, if approved, will establish South Africa as an equal player amongst other sugar-producing developing countries.

South Africa therefore relies on the liberalisation of markets in order to free itself from the continual trade distortions that seem to cloud the development of its sugar market. South Africa does not have the economic capacity or ability to be able to support its farmers in a way that will allow them to have a competitive advantage, protecting them from the continual disruptions within the sugar sector. It therefore relies upon further trade integration with the EU in order to facilitate its development in internal markets. The South African government hopes that initiating an EPA with the EU will assist in removing the disparity on the markets. It believes the future potential benefits of the agreement will lead to the protection of its internal market, opening up new trade and production opportunities that are currently unattainable. South Africa therefore continues to push for bilateral trade negotiations with the EU in order to secure the future prosperity of its markets.

The consequence of EU-South African trade agreements has clearly resulted in large disparities within the South African market. A prime example of this is the South African sugar sector. The industry has been hard hit by trying to adjust to the EU standards required by the terms of the trade partnership between the two countries. However, the South African government has raised concerns. It fears that whilst opening up its agricultural markets to the EU may benefit certain sectors, it may also be to the detriment of others.

\section{Future impact of the EU's internal market}

With nearly $96 \%$ of the world's farmers living in developing countries, ${ }^{92}$ supplying nearly 2.5 billion people with an adequate food supply, ${ }^{93}$ there is an overwhelming need to apply appropriate agricultural and development strategies to ensure optimal use of current available supplies. The EU is constantly seeking ways in which to enter these markets using its key player status. Its continual brokering of trade deals with developing economies has allowed it to gain access to untapped markets, thereby obtaining top resources at low costs for its own internal market. Through its own internal protectionist measures, it has sheltered its own economy, whilst developing those of others. In 2001, closed EU markets were said to have cost developing countries over USD 100 billion in lost opportunities. ${ }^{94}$

\footnotetext{
92 W Minter, 'Africa and the World Trade Organization: The Issues in Brief' (Foreign Policy in Focus, 2001) <http://www.fpif.org/articles/africa_and_the_world_trade_organization_ the_issues_in_brief> accessed 12 May 2011.

93 Minter (n 92).

94 Minter (n 92).
} 
In a study conducted by the World Bank, full trade liberalisation by developing countries is said to bring approximately USD 200 to 500 billion in additional income to them. ${ }^{95}$ This is made particularly clear in the agriculture sector, where agricultural subsidies to farmers in the EU are more than six times the amount that is afforded to developing countries for developmental assistance. ${ }^{96}$

Developing countries rely heavily on export earnings from their agricultural sector, with some countries' agricultural incomes contributing nearly 40\% towards their annual income. ${ }^{97}$ They are therefore reliant on trade negotiations with the EU in order to gain access to world markets. South Africa, a perfect example of a developing state (not yet considered a developed country, but hardly bundled into the harness of poverty-stricken countries that the rest of Africa is), uses its developing nation status to acquire trade deals with the EU. These trade agreements afford South Africa great potential and future gains for its economy, even if it is the expense of its neighbours or, to some extent, its own expense.

Even though the EU might have lowered its internal protectionist measures due to international pressure, it reaffirms these market restrictions in its trade agreements with developing countries. In turn, these EU market restrictions further undermine the internal development of the developing country. The EU clearly stated in its 2002 CAP reforms that whilst the reform process will improve market opportunities for developing countries, it is not the overall objective: enhancement of EU agriculture is. ${ }^{98}$ A central element in CAP reform has been the shift from price support to farmers to direct income support. Whilst government support for lower production levels is allowed, government support for increased production levels is not. Ironically, the latter is exactly what is needed in order to tackle the issue of food security in developing countries. However, the EU argues that in shifting aid to direct payments to farmers, it allows the prices of EU-produced agricultural commodities to fall without undermining farm incomes and production within the EU. ${ }^{99}$ However, developing countries do not have the means to protect or to subsidise local producers. This makes trading on an equal basis impossible, as the levels of development and competitiveness of the trading partners is vastly different.

\footnotetext{
95 D van der Mensbrugghe, 'Estimating the Benefits of Trade Reform: Why Numbers Change' in R Newfarmer (ed), Trade, Doha, and Development: A Window into the Issues (World Bank 2005) 1.

96 Minter (n 92).

97 Minter (n 92).

98 Minter (n 92).

99 P Goodison, 'What is the Future for EU-Africa Agricultural Trade after CAP Reform?' (2007) 34 (112) Review of African Political Economy 279, 289.
} 
The reforms of EU agricultural policy therefore seem to be a doubleedged sword. Whilst on the one hand they are seen to lower protectionist measures, on the other they increase levels of government support in other sectors, thereby decreasing the chances of developing farmers reaching optimal levels of supply and demand on international markets. It is therefore clear that any form of market support will result in a distortion of levels of trade in developing countries.

\subsection{Impact on South Africa}

Currently South Africa enjoys the trading privileges afforded to it by the TDCA agreement. However, this has resulted in a trade diversion from its previous trading arrangements with its neighbours. South Africa has been required to open its markets to the EU, eliminating importation costs in exchange for improved access to EU markets.

Since the inception of the trade deal with the EU, South Africa has also enjoyed an increase in political dialogue with the EU. This has resulted in its inclusion in discussions where the effects of future international trade deals and the consequences of global climatic concerns are a priority. The trade deal afforded South Africa not only economic benefits, but also an invitation to join the exclusive club of the world's most powerful nations. It feels the benefits of inclusion outweigh the costs.

The main issue, which seems to be a recurring problem in trade relations with the EU, is that South Africa is required to open its market, allowing full EU access, whilst the EU fails to open its own internal markets to the same extent.

A further concern for the South African sugar sector is the control that EU-based companies will have in South African markets. In a recent development, Associated British Foods (ABF) bought a majority share in Illovo Sugar (an African-based production company). ${ }^{100}$ Entry into the African market by ABF secured $40 \%$ of South African sugar production, doubling the total level of sugar production ABF controlled globally. South Africa and its neighbours fear the impact that this EU powerhouse will have on its markets. ${ }^{101}$ Local producers and government officials alike worry whether ABF will exploit local markets in order to serve European or international markets, exploiting South Africa as a low-cost supplier of raw sugar. This has resulted in huge concerns within the African market regarding the effects of trade liberalisation in the region.

In the case of South Africa, liberalising local markets and thereby allowing duty-free access to certain products (such as sweets and cho-

\footnotetext{
${ }^{100}$ Goodison (n 99) 284.
}

${ }^{101}$ Goodison (n 99) 284. 
colate), whilst at the same time trying to protect its basic agriculture (eg sugar), has resulted in undermining the competitive position of local companies on national and regional markets. ${ }^{102}$ This however, appears to be a double-edged sword. In order for South Africa to compete and enter international markets, it needs to open up its markets to EU investment.

\section{Conclusion}

South Africa's entry into the European market has afforded it new trade advantages and infinite investment opportunities. However, it has also been to the detriment of its neighbours, whereby the exclusion of previous trading partners has often led to a loss in national integration. The South African-EU partnership has therefore come at a price. However, this heavy price is yet to be seen. Whether or not the South African government is able to stand its ground against this major trade superpower will establish future trade relations.

If the EU were to eliminate all of its tariff barriers when trading with South Africa, European farmers would still be at an advantage. Despite EU farming methods being expensive and South Africa having a competitive advantage with the goods that they are able to produce, the EU enhances its agricultural sector through various support structures and large subsidies that the South African government is unable to compete with.

This paper has sought to examine the development of two distinct trading partners. Whilst huge disparities still exist, both the EU and South Africa have used the TDCA to benefit their internal markets through improved market access.

${ }^{102}$ Goodison (n 99) 284. 